\title{
The burden of illness in patients with moderate to severe chronic obstructive pulmonary disease in Canada
}

\author{
M Reza Maleki-Yazdi MD FRCPC FCCP ${ }^{1}$, Suzanne M Kelly PhD², Sy S Lam MD³, \\ Mihaela Marin MD MSc ${ }^{4}$, Martin Barbeau MSc ${ }^{2}$, Valery Walker MSc ${ }^{4}$
}

MR Maleki-Yazdi, SM Kelly, SS Lam, M Marin, M Barbeau, V Walker. The burden of illness in patients with moderate to severe chronic obstructive pulmonary disease in Canada. Can Respir J 2012;19(5): 319-324.

INTRODUCTION: No recent Canadian studies with physician- and spirometry-confirmed diagnosis of chronic obstructive pulmonary disease (COPD) that assessed the burden of COPD have been published.

OBJECTIVE: To assess the costs associated with maintenance therapy and treatment for acute exacerbations of COPD (AECOPD) over a oneyear period.

METHODS: Respirologists, internists and family practitioners from across Canada enrolled patients with an established diagnosis of moderate to severe COPD (Global initiative for chonic Obstructive Lung Disease stages 2 and 3) confirmed by postbronchodilator spirometry. Patient information and health care resources related to COPD maintenance and physician-documented AECOPD over the previous year were obtained by chart review and patient survey.

RESULTS: A total of 285 patients (59.3\% male; mean age 70.4 years; mean pack years smoked 45.6; mean duration of COPD 8.2 years; mean postbronchodilator forced expiratory volume in $1 \mathrm{~s} 58.0 \%$ predicted) were enrolled at 23 sites across Canada. The average annual COPD-related cost per patient was $\$ 4,147$. Across all 285 patients, maintenance costs were $\$ 2,475$ per patient, of which medications accounted for $71 \%$. AECOPD treatment costs were $\$ 1,673$ per patient, of which hospitalizations accounted for $82 \%$. Ninety-eight patients (34\%) experienced a total of 157 AECOPD. Treatment of these AECOPD included medications and outpatient care, 19 emergency room visits and 40 hospitalizations (mean length of stay 8.9 days). The mean cost per AECOPD was $\$ 3,036$.

DISCUSSION: The current costs associated with moderate and severe COPD are considerable and will increase in the future. Appropriate use of medications and strategies to prevent hospitalizations for AECOPD may reduce $\mathrm{COPD}$-related costs because these were the major cost drivers.

Key Words: Burden of illness; Chronic obstructive pulmonary disease; Cost of illness; Costs; Exacerbations; Health care resource use

$\mathrm{C}$ hronic obstructive pulmonary disease (COPD) is a respiratory disorder largely caused by smoking, and is characterized by progressive, partially reversible airway obstruction and lung hyperinflation, systemic manifestations, and increasing frequency and severity of acute exacerbations of COPD (AECOPD) $(1,2)$.

AECOPD are primarily triggered by respiratory tract infections and are characterized by symptomatic, physiological and functional deteriorations leading to an increase in the use of maintenance medications and/or addition of medications (1). The impact of AECOPD includes the following: accelerated rate of decline in lung function (3); reduction in health-related quality of life (4); increased risk of hospitalization (5); significant increase in health care cost (6); and decreased survival (7). Therefore, prevention of AECOPD is a key component of COPD management.

\author{
Le fardeau de la maladie chez les patients ayant une \\ maladie pulmonaire obstructive chronique modérée \\ à grave au Canada
}

INTRODUCTION : Aucune étude canadienne récente n'a été publiée sur les patients atteints d'une maladie pulmonaire obstructive chronique (MPOC) dont le diagnostic est confirmé par le médecin et par spirométrie et qui évalue le fardeau de la MPOC.

OBJECTIF : Évaluer les coûts associés à la thérapie d'entretien et au traitement d'exacerbations aiguës de la MPOC (EAMPOC) sur une période d'un an.

MÉTHODOLOGIE : Des pneumologues, des internistes et des médecins de famille du Canada ont recruté des patients ayant un diagnostic établi de MPOC modérée à grave (initiative mondiale pour la maladie pulmonaire obstructive chronique de phases 2 et 3 ) confirmé par spirométrie après la prise de bronchodilatateurs. Ils ont obtenu l'information au sujet des patients, des ressources de santé liées au traitement d'entretien de la MPOC et des EAMPOC étayées par un médecin au cours de l'année précédente en analysant les dossiers et en distribuant un sondage aux patients.

RÉSULTATS : Au total, les chercheurs ont recruté 285 patients $(59,3 \%$ d'hommes; âge moyen de 70,4 ans; moyenne de paquets fumés par année : 45,6; durée moyenne de la MPOC : 8,2 ans; volume expiratoire maximal par seconde après la prise de bronchodilatateurs : $58,0 \%$ de la valeur prévue) dans 23 établissements du Canada. Le coût annuel moyen lié à la MPOC par patient s'élevait à 4147 \$. Chez les 285 patients, les coûts d'entretien s'élevaient à 2475 \$ par patient, et les médicaments représentaient $71 \%$ de ces coûts. Les coûts du traitement de l'EAMPOC correspondaient à 1673 \$ par patient, et les hospitalisations représentaient $82 \%$ de ces coûts. Quatrevingt-dix-huit patients ( $34 \%$ ) ont subi un total de 157 EAMPOC. Le traitement de ces EAMPOC incluait des médicaments et des soins ambulatoires, 19 consultations à l'urgence et 40 hospitalisations (hospitalisation moyenne de 8,9 jours). Le coût moyen par EAMPOC s'élevait à $3036 \$$.

EXPOSÉ : Les coûts actuels associés à une MPOC modérée ou grave sont considérables et augmenteront à l'avenir. L'utilisation convenable des médicaments et des stratégies pour prévenir les hospitalisations causées par des EAMPOC pourraient réduire les coûts liés à une MPOC parce que ce sont là des générateurs de coûts majeurs.

COPD is significantly underdiagnosed because spirometry is not routinely performed on all at-risk patients, particularly in early disease. For example, a 2007 Canadian study (8) showed that in a population at risk for the disease, $36 \%$ actually had a spirometric diagnosis of COPD. The prevalence and burden of COPD are projected to increase in the coming decades. A recent report by the Ontario Lung Association (9) highlighted a current prevalence of 5.9\% and a projected increase to $6.9 \%$ of the Ontario population by 2041. A longitudinal study conducted in Ontario reported an overall lifetime risk of physician-diagnosed COPD at 80 years of age to be $27.6 \%$ (10).

There is considerable evidence that COPD management is not in accordance with current guidelines $(2,11-13)$, possibly contributing to COPD-related costs. The costs of COPD are high and increase with the severity of the disease (14). Although COPD represents a major

${ }^{1}$ Women's College Hospital, Department of Medicine, University of Toronto, Toronto, Ontario; ${ }^{2}$ Novartis Pharmaceuticals Canada Inc, Dorval,

Quebec; ${ }^{3}$ University of Calgary, Calgary West Medical Centre, Calgary, Alberta; ${ }^{4}$ OptumInsight, Burlington, Ontario

Correspondence and reprints: Dr M Reza Maleki-Yazdi, Division of Respiratory Medicine, Women's College Hospital, 790 Bay Street,

Suite 608, Toronto, Ontario M5G 1N8. Telephone 416-921-7704, fax 416-921-3277, e-mail maleki.pccrc@on.aibn.com 


\section{TABLE 1 \\ Unit costs for outpatient resources, hospitalizations and time loss from work}

\begin{tabular}{|c|c|c|}
\hline Type of resource & Cost, \$CAD (2009) & Source \\
\hline \multicolumn{3}{|l|}{ Health care professionals } \\
\hline $\begin{array}{l}\text { Family physician: 1st visit; 2nd and } \\
\text { subsequent visits }\end{array}$ & $68.75 ; 32.35$ & OSB-PS \\
\hline $\begin{array}{l}\text { Respirologist: 1st visit; 2nd visit; 3rd } \\
\text { visit; 4th and subsequent visits }\end{array}$ & $\begin{array}{c}143.40 ; 68.75 \\
33.70 ; 20.00\end{array}$ & OSB-PS \\
\hline $\begin{array}{l}\text { Internist: 1st visit; 2nd visit; 3rd visit; } \\
\text { 4th and subsequent visits }\end{array}$ & $\begin{array}{c}143.40 ; 68.75 \\
33.70 ; 20.00\end{array}$ & OSB-PS \\
\hline Allergist & 89.30 & OSB-PS \\
\hline Thoracic specialist & 89.30 & OSB-PS \\
\hline Dietician & 58.00 & LHSC \\
\hline Occupational therapist & 69.00 & LHSC \\
\hline Physiotherapist & 66.00 & LHSC \\
\hline Respiratory therapist & 80.00 & LHSC \\
\hline Pulmonary medicine nurse practitioner & 45.00 & LHSC \\
\hline Walk-in clinic & 32.35 & OSB-PS \\
\hline Home care visit & 52.30 & $\mathrm{CCHS}$ \\
\hline General practitioner home visit & 41.75 & OSB-PS \\
\hline Smoking cessation counselling & 48.85 & OSB-PS \\
\hline \multicolumn{3}{|l|}{ Procedures } \\
\hline Spirometry & 38.23 & OSB-PS \\
\hline Walk test & 32.45 & OSB-PS \\
\hline Electrocardiogram & 16.50 & OSB-PS \\
\hline Chest x-ray & 33.75 & OSB-PS \\
\hline Pulmonary function test & 149.42 & OSB-PS \\
\hline Bronchoscopy & 131.48 & OSB-PS and OSB-LF \\
\hline Computed tomography scan & 79.85 & OSB-PS \\
\hline Thorax scan & 79.85 & OSB-PS \\
\hline Magnetic resonance imaging & 77.20 & OSB-PS \\
\hline Echocardiogram & 205.95 & OSB-PS \\
\hline Blood tests & 8.27 & OSB-LF \\
\hline Blood gases & 21.10 & OSB-PS \\
\hline Blood culture & 15.51 & OSB-LF \\
\hline Sputum culture/Gram stain & 11.37 & OSB-LF \\
\hline Cytology expectorant & 6.72 & OSB-LF \\
\hline Ventilation-perfusion lung scan & 79.85 & OSB-PS \\
\hline \multicolumn{3}{|l|}{ Rehabilitation } \\
\hline Exercise training & 132.00 & LHSC \\
\hline Smoking cessation counselling & 48.85 & OSB-PS \\
\hline Patient teaching and self-management & 48.85 & OSB-PS \\
\hline Swimming & 184.95 & $\begin{array}{l}\text { South-Common } \\
\text { indoor pool* }\end{array}$ \\
\hline \multicolumn{3}{|l|}{ Devices $^{\dagger}$} \\
\hline Wheelchair & 169.50 & $\mathrm{SHHC}$ \\
\hline Walker & 98.88 & $\mathrm{SHHC}$ \\
\hline Nebulizer machine & 68.36 & $\mathrm{SHHC}$ \\
\hline Electric scooter & 847.50 & $\mathrm{SHHC}$ \\
\hline Cane & 3.55 & $\mathrm{SHHC}$ \\
\hline $\begin{array}{l}\text { Continuous positive airway } \\
\text { pressure machine }\end{array}$ & 163.57 & CPAP.com \\
\hline Oxygen & 798.00 & $\begin{array}{l}\text { Canadian Home } \\
\text { Healthcare }\end{array}$ \\
\hline Ambulance ride & 500.00 & $\begin{array}{l}\text { Ministry of Health } \\
\text { and Long-Term Care }\end{array}$ \\
\hline \multicolumn{3}{|l|}{ Emergency room visits } \\
\hline Hospital emergency & $471.74^{\ddagger}$ & $\mathrm{OCCl}$ \\
\hline $\begin{array}{l}\text { Emergency department physician } \\
\text { fee }\end{array}$ & 65.10 & OSB-PS \\
\hline \multicolumn{3}{|l|}{ Hospitalizations } \\
\hline Hospital daily cost & $1,063.99^{\ddagger}$ & $\mathrm{OCCl}$ \\
\hline $\begin{array}{l}\text { Hospital physician: 1st day; } \\
\text { subsequent days }\end{array}$ & $\begin{array}{c}143.40 \\
29.20\end{array}$ & OSB-PS \\
\hline Time loss from work (full day) & 181.35 & Statistics Canada \\
\hline
\end{tabular}

${ }^{\star}$ Mississauga, Ontario; ${ }^{\dagger}$ Costs for devices were divided by the useful life years to obtain an annual cost; ${ }^{\ddagger}$ Adjusted to 2009 cost. CCHS ComCare Health Services; LHSC London Health Sciences Centre, London, Ontario; OCCI Ontario Case Costing Initiative; OSB-LF The Ontario Schedule of Benefits for Laboratory Fees; OSB-PS The Ontario Schedule of Benefits for Physician Services; SHHC Shoppers Home Health Care, Canada health issue in Canada, no recent Canadian studies with physicianand spirometry-confirmed diagnosis of COPD have been published that assess the complete cost of illness and its overall burden to the health care system.

A Canadian survey of COPD patients conducted in 2000/2001 reported an annual COPD-related cost of $\$ 3,195$ per patient (15). In addition, the prospective Resource Use Study in COPD (RUSIC), conducted in 2001/2002, reported costs to the health care system of $\$ 641$ and $\$ 9,557$ per patient for moderate and severe AECOPD, respectively (16).

The objective of the present study was to assess the direct and indirect costs associated with maintenance therapy and treatment for AECOPD in a real-world setting over a one-year period among patients with moderate to severe (Global initiative for chronic Obstructive Lung Disease [GOLD] 2 and 3) COPD using data from patient medical records and patient surveys.

Study design and participants

\section{METHODS}

The present study was a retrospective chart review including a patient survey. A sample size of 300 was selected based on the precision needed to estimate the primary end point of annual cost per patient. The patients completed a survey on the day they were enrolled. Data abstraction from the patient chart or electronic medical records was completed by the site staff for the year before the date the patient was surveyed.

Patients were enrolled between October 31, 2009 and January 31, 2010, from 23 general practitioner/family physician (GP/FP) and specialist (respirologist and internist) sites across Canada. The study protocol and patient informed consent received institutional review board approval. The sites assessed patients for eligibility as they presented to the physician's office for regularly scheduled visits, and were encouraged to enroll patients who were in GOLD stages 2 and 3.

Inclusion criteria were as follows: $\geq 50$ years of age; smoking history $\geq 20$ pack years; diagnosis of COPD at least one year before study (confirmed by postbronchodilator spirometry within the past year or after patient provided informed consent); postbronchodilator forced expiratory voloume in $1 \mathrm{~s}\left(\mathrm{FEV}_{1}\right) /$ forced vital capacity $(\mathrm{FVC})<70 \%$ and moderate to severe COPD (postbronchodilator $\mathrm{FEV}_{1}<80 \%$ and $\geq 30 \%$ of predicted). Patients were required to have documentation of receipt of care for COPD at the site over the past year.

Exclusion criteria were as follows: participation in any clinical trial within the past year; long-term oxygen therapy ( $>15 \mathrm{~h} /$ day) for chronic hypoxemia; history of concomitant pulmonary disease (eg, pulmonary fibrosis, active pulmonary tuberculosis, clinically significant bronchiectasis; history of asthma and/or onset of respiratory symptoms (eg, cough, wheeze, shortness of breath) before 40 years of age; and history of lung cancer.

\section{Outcome measures}

AECOPD were defined as sustained $(>48 \mathrm{~h}$ ) worsening of dyspnea, cough or sputum production leading to an increase in the use of maintenance medications and/or supplementation with additional medication (as defined in the Canadian Thoracic Society guidelines). The site investigator identified whether an AECOPD occurred from documentation of the exacerbation and any new medication and/or change in medication treatment that was contained in the patient's chart (1). The site provided the number and type of health care resources used for maintenance treatment of COPD (when patients were not experiencing an AECOPD as defined above). Resources related to an AECOPD were provided if one occurred. The patients provided information that was not expected to be in the chart (rehabilitation, medical devices, time missed from work and out-of-pocket expenses). Resources collected in the study were assigned costs from the province of Ontario and are reported in Canadian dollars (adjusted to 2009). The individual costs are listed in Table 1. For patients who were hospitalized, the study did not collect data regarding whether the patient 
TABLE 2

Patient demographics and chronic obstructive pulmonary disease (COPD) characteristics

\begin{tabular}{|c|c|c|c|}
\hline & \multicolumn{3}{|c|}{ Patients } \\
\hline & $\begin{array}{c}\text { All } \\
(n=285)\end{array}$ & $\begin{array}{c}\text { Male } \\
(n=169)\end{array}$ & $\begin{array}{l}\text { Female } \\
(n=116)\end{array}$ \\
\hline Age, years & $70.4 \pm 9.4$ & $70.4 \pm 9.5$ & $70.4 \pm 9.2$ \\
\hline $\mathrm{FEV}_{1} / \mathrm{FVC}$ ratio*,$\%$ & $56.4 \pm 13.6$ & $56.3 \pm 13.7$ & $56.6 \pm 13.6$ \\
\hline $\mathrm{FEV}_{1}, \%$ predicted & $58 \pm 18.3$ & $55.9 \pm 16.7$ & $61.1 \pm 20.1$ \\
\hline \multicolumn{4}{|l|}{ GOLD COPD severity ${ }^{\dagger}, \mathrm{n}(\%)$} \\
\hline GOLD 1 & $35(12.3)$ & $15(8.9)$ & $20(17.2)$ \\
\hline GOLD 2 & $145(50.9)$ & $87(51.4)$ & $58(50.0)$ \\
\hline GOLD 3 & $94(33.0)$ & $57(33.7)$ & 37 (31.9) \\
\hline GOLD 4 & $11(3.9)$ & $10(5.9)$ & $1(0.9)$ \\
\hline COPD duration, years & $8.2 \pm 7.4$ & $8.7 \pm 7.9$ & $7.5 \pm 6.6$ \\
\hline \multicolumn{4}{|l|}{ Smoking status, n (\%) } \\
\hline Current smoker & $105(36.8)$ & $57(33.7)$ & $48(41.4)$ \\
\hline Ex-smoker & $178(62.5)$ & $110(65.1)$ & $68(58.6)$ \\
\hline Missing & $2(0.7)$ & $2(1.2)$ & $0(0)$ \\
\hline Smoking, pack-years & $45.6 \pm 20.7$ & $47.2 \pm 22.0$ & $43.2 \pm 18.5$ \\
\hline \multicolumn{4}{|l|}{ Employment status ${ }^{\ddagger}, \mathrm{n}(\%)$} \\
\hline Retired & $201(70.5)$ & $118(69.8)$ & $83(71.6)$ \\
\hline Full-time & $37(13.0)$ & $29(17.2)$ & $8(6.9)$ \\
\hline Part-time & $16(5.6)$ & $7(4.1)$ & $9(7.8)$ \\
\hline Homemaker & $13(4.6)$ & $1(0.6)$ & $12(10.3)$ \\
\hline Other & $21(7.6)$ & $16(9.5)$ & $5(4.4)$ \\
\hline Missing & $6(2.1)$ & $4(2.4)$ & $2(1.7)$ \\
\hline \multicolumn{4}{|l|}{ Drug plan ${ }^{\ddagger}, \mathrm{n}(\%)$} \\
\hline Any health plan & $265(93.0)$ & $157(92.9)$ & $108(93.1)$ \\
\hline Government health plan & $196(68.8)$ & $105(62.1)$ & $91(78.4)$ \\
\hline Employer health plan & $66(23.2)$ & $39(23.1)$ & $27(23.3)$ \\
\hline Private health plan & $25(8.8)$ & $20(11.8)$ & $5(4.3)$ \\
\hline No health plan & $20(7.0)$ & $12(7.1)$ & $8(6.9)$ \\
\hline Other $§$ & $8(2.8)$ & $5(3.0)$ & $3(2.6)$ \\
\hline \multicolumn{4}{|l|}{ Comorbidities $^{\ddagger}, \mathrm{n}(\%)$} \\
\hline$\geq 1$ comorbidities & $273(95.8)$ & $158(93.5)$ & $115(99.1)$ \\
\hline Cardiovascular & $214(75.1)$ & $128(75.7)$ & $86(74.1)$ \\
\hline $\begin{array}{l}\text { Musculoskeletal and } \\
\text { connective tissue }\end{array}$ & $130(45.6)$ & $63(37.3)$ & $67(57.8)$ \\
\hline Gastrointestinal & $75(26.3)$ & $44(26.0)$ & $31(26.7)$ \\
\hline $\begin{array}{l}\text { Endocrine/metabolic/nutrition } \\
\text { disease }\end{array}$ & $69(24.2)$ & $37(21.9)$ & $32(27.6)$ \\
\hline Psychiatric & $62(21.8)$ & $36(21.3)$ & $26(22.4)$ \\
\hline Sleep disorders & $41(14.4)$ & $27(16.0)$ & $14(12.1)$ \\
\hline Other" & $104(37.0)$ & $70(41.6)$ & $34(29.4)$ \\
\hline
\end{tabular}

Data presented as mean $\pm S D$ unless otherwise indicated. ${ }^{*}$ There were 36 patients with forced expiratory volume in $1 \mathrm{~s}$ ( $\left.F E V_{1}\right)$ /forced vital capacity (FVC) ratios $>70 \%$ on their most recent spirometry. However, all patients had a previously confirmed diagnosis of COPD by their physicians. ${ }^{\dagger}$ Global initiative for chronic Obstructive Lung Disease (GOLD) 1: Mild (FEV $1 \%$ predicted $\geq 80 \%$ ); GOLD 2: Moderate (50\% $\leq F E V_{1} \%$ predicted <80\%); GOLD 3: Severe $(30 \%$ $\leq F E V_{1} \%$ predicted <50\%); GOLD 4: Very severe (FEV $1 \%$ predicted $<30 \%$ ); ${ }^{\ddagger}$ Patients may report more than one response; ${ }^{S}$ Other drug plans included the following: self $(n=1)$, workers compensation $(n=1)$, spouse $(n=2), 50 \%$ done by self $(n=1)$, percentage $(n=1)$, missing $(n=2)$; "Some of the other comorbidities that were reported by more than $5 \%$ of patients were cancer (excluding lung), kidney disease and neurological disorders. Each of the remaining comorbidities was reported by fewer than $5 \%$ of patients

was admitted to the ward or the intensive care unit. The discharge diagnosis and dates of admission and discharge were collected. This information was used to obtain a hospital cost from the Ontario Case Cost Initiative (OCCI) Costing Analysis Tool (17). The cost model provides fully allocated costs and includes the cost of days spent on the

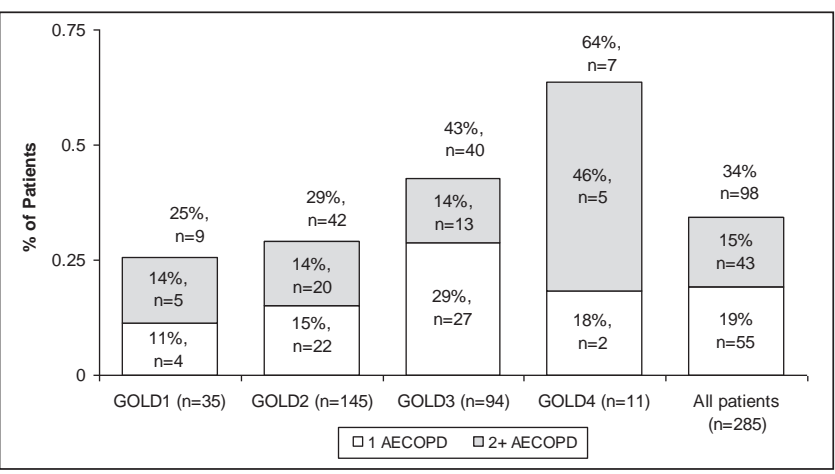

Figure 1) Annual frequency of acute exacerbations of chronic obstructive pulmonary diease (AECOPD) per patient according to Global initiative for chronic Obstructive Lung Disease (GOLD) COPD severity

ward and days spent in the intensive care unit. The daily cost from the $\mathrm{OCCI}$ and the cost for physician was applied to the number of days for each hospitalization. The cost of emergency room visits were also obtained from the OCCI.

Data analysis

As part of the analysis, $\mathrm{FEV}_{1} \%$ predicted was recalculated for all patients using the equations provided by the European Community for Coal and Steel (18). The recalculated values were used to categorize patients according to COPD GOLD severity (GOLD 1 to 4). For this reason, patients may have been reassigned to GOLD stage 1 or 4 , even though the inclusion criteria required them to be GOLD stage 2 or 3 .

\section{RESULTS}

Forty-eight per cent of the patients were enrolled by GP/FPs and $52 \%$ were enrolled by specialists. Demographics and COPD severity are shown in Table 2 for all patients enrolled and also according to sex. The majority of patients were in GOLD stage 2 or 3 , and $95.8 \%$ had one or more comorbidities.

Of the 98 patients (34\%) who experienced at least one AECOPD in the previous year, $55(19.3 \%)$ had one, $31(10.9 \%)$ had two, nine (2\%) had three, two $(0.7 \%)$ had four and one $(0.4 \%)$ had five, yielding a total of 157 AECOPD. Figure 1 provides the number of patients with one AECOPD and $\geq 2$ AECOPD according to GOLD COPD severity. At GOLD 4, the percentage of patients with $\geq 2$ AECOPD was three times higher than it was at other severity levels. However, the number of patients in GOLD 4 was small; therefore, these results should be interpreted with caution.

For maintenance treatment of COPD, $68.8 \%$ of patients were taking inhaled corticosteroids (ICS)/long-acting beta ${ }_{2}$-agonist (LABA) combinations, $67.7 \%$ were taking long-acting anticholinergics (LAACs) and $65.6 \%$ were taking short-acting beta -agonists (SABAs) (Figure 2). In these categories, the most commonly used medications for maintenance treatment were tiotropium (67.7\%), salbutamol $(63.2 \%)$ and salmeterol/fluticasone (54.4\%) (data not shown). When evaluated according to GOLD severity, the percentage of patients taking each medication was greater in the patients with more severe COPD (ie, GOLD 3 and 4). Medications to treat AECOPD included antibiotics $(85.7 \%$ of the 98 patients with $\geq 1$ AECOPD), systemic corticosteroids $(57.1 \%)$, SABAs $(25.5 \%)$, ICS/LABA combinations $(11.2 \%)$ and others (15.3\%).

Only $18.2 \%$ of patients participated in a rehabilitation program; the most common programs were exercise training (12.6\%), patient teaching and self management (4.6\%), and smoking cessation $(2.8 \%)$. The health care professionals most frequently seen were GP/FP $(56.8 \%$ of patients), respirologists (56.1\%) and respiratory therapists (16.1\%). Over the year, the mean number of GP/FP visits was 2.63 per patient (range 0 to 23 per patient) and the mean number of respirologist visits was 1.57 per patient (range 0 to 15 per patient). The most frequently performed procedures were spirometry $(75.8 \%)$, chest $\mathrm{x}$-ray $(42.1 \%)$, 


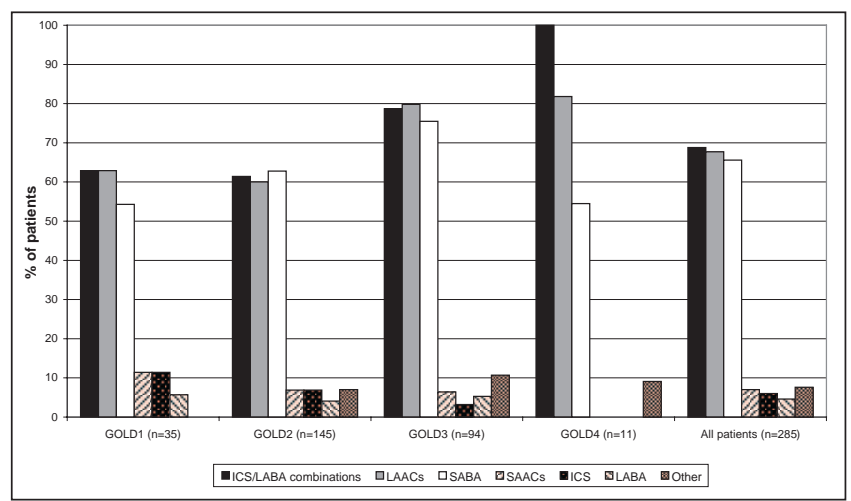

Figure 2) Use of medications for chronic obstructive pulmonary disease (COPD) maintenance treatment according to Global initiative for chronic Obstructive Lung Disease (GOLD) COPD severity. ICS Inhaled corticosteroids; LAACs Long-acting anticholinergics; LABA Long-acting beta ${ }_{2}$ agonist combinations; SABA Short-acting beta ${ }_{2}$-agonist; SAACs Short-acting anticholinergics; SCS Systemic corticosteroids. Other includes antibiotics, SCS, leukotriene receptor antagonists and theophylline (each used by less than $2 \%$ of all patients). Note: More than one medication class can be used per patient

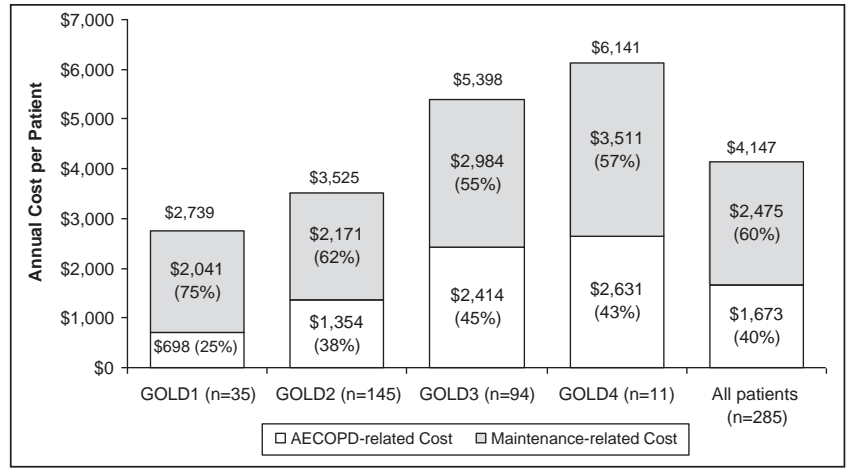

Figure 3) Annual chronic obstructive pulmonary disease (COPD)-related costs (\$CAD 2009) per patient according to Global initiative for chronic Obstructive Lung Disease (GOLD) COPD severity. AECOPD Acute exacerbation of COPD

full pulmonary function testing (24.6\%) and electrocardiogram (15.1\%). The mean number of spirometry tests was 1.46 per patient (range 0 to 8 per patient); mean number of chest $\mathrm{x}$-rays was 0.66 per patient (range 0 to 6 per patient); and mean number of full pulmonary function tests was 0.31 per patient (range 0 to 7 per patient). Spirometry performed to evaluate eligibility for the study was not included.

There were a total of 28 emergency room visits ( 19 for AECOPD according to the definition used in the present study) and 45 hospitalizations (40 for AECOPD). The mean length of hospital stay for an AECOPD was 8.9 days (range 2.0 to 25.0 days). Of all patients, $4.6 \%$ reported missing time from work due to COPD (mean one day per patient), and $1.8 \%$ said their caregivers missed time from work due to patients' COPD (mean 0.4 days per patient).

The mean $( \pm \mathrm{SD})$ annual total COPD-related cost per patient was $\$ 4,147 \pm 6,255$. The total cost and the AECOPD- and maintenancerelated costs increased with increased severity level (Figure 3 ).

The cost for treatment of AECOPD was $\$ 1,673$ per patient, which accounted for $40 \%$ of the total cost. Hospitalization cost (mean $\$ 1,376$ per patient) accounted for $82 \%$ of the mean total AECOPD cost (Table 3$)$. The largest cost driver for maintenance was the cost of medications ( $\$ 1,744$ per patient), which accounted for $71 \%$ of the mean total maintenance cost. The direct medical costs $(\$ 3,895$ per patient) accounted for $94 \%$ of the total costs, with only $6 \%$ attributable to time missed from work. The mean cost per AECOPD was $\$ 3,036$.
TABLE 3

Annual chronic obstructive pulmonary disease (COPD)related costs (maintenance-related and acute exacerbation of COPD [AECOPD]-related) for all patients and cost per AECOPD

\begin{tabular}{|c|c|c|c|c|}
\hline & \multicolumn{3}{|c|}{$\begin{array}{c}\text { Mean annual COPD-related } \\
\text { cost per patient* } \\
\text { All patients }(n=285), \$\end{array}$} & \multirow{2}{*}{ 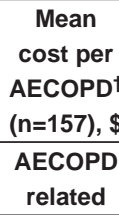 } \\
\hline & Total & $\begin{array}{l}\text { Maintenance } \\
\text { related }\end{array}$ & $\begin{array}{l}\text { AECOPD } \\
\text { related }\end{array}$ & \\
\hline Medications & 1,775 & 1,744 & 31 & 56 \\
\hline ER visits & 53 & 17 & 36 & 65 \\
\hline Hospitalizations & 1,497 & 121 & 1,376 & 2,498 \\
\hline Ambulance & 25 & 2 & 23 & 41 \\
\hline $\begin{array}{l}\text { Rehabilitation } \\
\text { programs }\end{array}$ & 22 & 22 & 0 & 0 \\
\hline Medical devices & 27 & 27 & 0 & 0 \\
\hline $\begin{array}{l}\text { Health care } \\
\text { professionals }\end{array}$ & 306 & 257 & 48 & 88 \\
\hline Procedures & 145 & 129 & 16 & 28 \\
\hline $\begin{array}{l}\text { Patient travel to } \\
\text { health care } \\
\text { professional }\end{array}$ & 46 & 41 & 6 & 9 \\
\hline Direct costs & 3,895 & 2,360 & 1,535 & 2,786 \\
\hline $\begin{array}{l}\text { Patient's } \\
\text { missed time } \\
\text { from work }\end{array}$ & 179 & 88 & 92 & 166 \\
\hline $\begin{array}{l}\text { Caregiver's } \\
\text { missed time } \\
\text { from work }\end{array}$ & 73 & 27 & 46 & 83 \\
\hline Indirect costs & 252 & 115 & 137 & 249 \\
\hline Total & 4,147 & 2,475 & 1,673 & 3,036 \\
\hline
\end{tabular}

Costs presented in \$CAD (2009). *The mean annual COPD-related cost per patient is the mean cost across all 285 patients for total cost, separated out for maintenance-related and AECOPD-related costs, and further broken down according to type of resource. The AECOPD-related costs include costs for patients who had no AECOPD and whose AECOPD-related cost would be $\$ 0$; tThe mean cost per AECOPD is the mean cost for the 157 AECOPD. This is calculated by dividing the AECOPD-related costs for all patients by 157 AECOPD. For example, the mean AECOPD-related cost per patient is $\$ 1,673$, and there were 285 patients. The total AECOPD-related cost is 285 patients $x$ $\$ 1,672.51=\$ 476,665$. There were 157 AECOPD; therefore, the average cost of an AECOPD is $\$ 476,665 / 157$ AECOPD $=\$ 3,036$ per AECOPD. ER Emergency room

\section{DISCUSSION}

One-third (34\%) of patients in the present study experienced at least one AECOPD, and the cost for treatment of an AECOPD was $\$ 1,673$ per patient, which accounted for $40 \%$ of the total annual cost. The frequency of AECOPD and related costs increased in those in more advanced stages of the disease. Hospitalization cost (mean \$1,376 per patient) accounted for $82 \%$ of the mean total AECOPD cost.

In a previous Canadian study, Mittmann et al (16) reported an overall cost per moderate AECOPD of $\$ 641$, and $\$ 9,557$ per severe AECOPD. There were 609 participants and 790 AECOPD, of which $639(81 \%)$ were moderate and $151(19 \%)$ were severe. Hospitalization was required in $151(19 \%)$ compared with 40 (25\%) of the 157 AECOPD in our study. Mittmann et al (16) did not report an average cost per AECOPD; however, an average can be calculated using the following formula: ( $\$ 641$ per moderate AECOPD $\times 639$ moderate AECOPD + $\$ 9,557$ per severe $\mathrm{AECOPD} \times 151$ severe $\mathrm{AECOPD}) / 790$ total AECOPD $=\$ 2,345$. This cost is lower than the direct cost per AECOPD in our study $(\$ 2,786)$, even after adjusting their costs to 2009 figures $(\$ 2,486)$; however, the study designs were different. 
The mean annual total cost per patient in our study $(\$ 4,147)$ was higher than the $\$ 3,196$ reported in 2003 by Chapman et al (15) ( $\$ 1,997$ in direct medical costs and $\$ 1,198$ for work lost), even after adjusting their costs to 2009 figures $(\$ 3,583)$. However, their study was a telephone survey, whereas ours was based on chart review as well as patient survey and was less dependent on patient recall. In our study, COPD medications contributed to $71 \%$ of the annual cost of maintenance treatment, and this cost was approximately three times higher than that reported in the Chapman et al (15) study. This difference can be explained by the following: $92 \%$ of our study patients took maintenance medication compared with $62 \%$ of patients in the Chapman et al (15) survey; our patients had more severe COPD; and we evaluated a more comprehensive list of costs. The cost of work loss in the Chapman et al $(15)$ survey $(\$ 1,198)$ was almost five times higher than in our study (\$252). As expected, because $71 \%$ of our patients were retired (compared with $32 \%$ in the Chapman et al [15] survey), work loss costs were lower in our study.

It is of interest to evaluate medication use in the present study in light of treatment guidelines. We observed that only $25 \%$ of GOLD 1 and $29 \%$ of GOLD 2 patients experienced an AECOPD in the previous year, but $62.9 \%$ of GOLD 1 and $61.4 \%$ of GOLD 2 patients were on an inhaled ICS/LABA combination. This is not consistent with the Canadian guidelines, which recommend that regular therapy with ICS/LABA be used only in patients with GOLD 2 and higher with $\geq 1$ AECOPD per year (1). Because the prevalence of mild and moderate COPD is greater than the prevalence of severe and very severe COPD, this approach may result in significant overspending of health care dollars. Use of LAACs and the ICS/LABA combination was consistent with treatment guidelines in the majority of GOLD 3 and GOLD 4 patients (LAACs: $79.8 \%$ and $81.8 \%$, respectively; ICS/LABA combination: $78.0 \%$ and $100.00 \%$, respectively).

Although $36.8 \%$ of patients were current smokers, fewer than 3\% were participating in a smoking cessation program. The current guidelines emphasize that smoking cessation is the single most effective and cost-effective intervention to stop the progression of COPD (2). Therefore, more effective physician advice and readily available antismoking treatment may help to reduce cost and COPD-related complications.

The main strength of the study was that we evaluated patients with physician-diagnosed COPD confirmed with postbronchodilator spirometry, which allowed classification according to GOLD/Canadian Thoracic Society guidelines $(1,2)$. In addition, resource use was collected primarily from patient charts and supplemented with patient surveys for data not expected to be in the charts. Finally, patients were enrolled from GP/FP and specialist sites across Canada, which makes the results generalizable if practice patterns are similar to those in the study. The exclusion/inclusion criteria were less restrictive than they would have been in an efficacy trial, thus increasing the generalizability of the results.

\section{Limitations}

Patients were included in the study based on the \% predicted $\mathrm{FEV}_{1}$ measured at the site. However, to standardize the spirometric data, measured values were expressed as a percentage of the European Community for Coal and Steel predicted values. Because of this, 35 patients (12\%) were reclassified as GOLD 1 and 11 patients (4\%) as GOLD 4. However, $84 \%$ fell within our predefined study population, and the cost and AECOPD results were not significantly different from those observed for patients in the immediately adjacent GOLD category (Figures 1 and 3).

Patients with long-term oxygen therapy ( $>15 \mathrm{~h} /$ day for chronic hypoxemia) were excluded from the study because they would be more likely to have very severe COPD (GOLD 4) and multiple comorbidities that would incur costs, making those attributable to COPD difficult to estimate. Only two patients were excluded from the study for this reason; however, the true cost of COPD may be greater than our findings.
Despite the inclusion criterion requiring patients to have a postbronchodilator $\mathrm{FEV}_{1} / \mathrm{FVC}$ ratio $<70 \%$ on a test completed within the past year, there were 36 patients with $\mathrm{FEV}_{1} / \mathrm{FVC}$ ratio $\geq 70 \%$ on their most recent spirometry. Because these patients had confirmed physiciandiagnosed COPD, and the results obtained when they were included $(n=285)$ did not differ from the results obtained when they were excluded $(n=248)$, the decision was made to include them in the analyses, consistent with a true intent-to-treat analysis.

\section{CONCLUSION}

The burden associated with moderate to severe COPD is currently considerable in terms of costs to the Canadian health care system. It is expected that the prevalence of COPD and its associated costs will continue to increase for the foreseeable future. Our results indicate that the two major cost contributors were medications and hospitalizations. Therefore, more appropriate use of medications to treat COPD, particularly in the early stages of the disease, and strategies to optimally detect, manage and prevent AECOPD at all levels of disease severity, may reduce COPD-related complications and the overall burden of the disease. Finally, because COPD is a heterogeneous disease, more research is required to understand the characteristics of each patient to provide the best individualised intervention.

AUTHOR CONTRIBUTIONS: M Reza Maleki-Yazdi, Suzanne M Kelly and Valery Walker contributed substantially to the concept, design and interpretation of data, drafted the manuscript and gave final approval. Sy S Lam and Martin Barbeau contributed to the concept and design, and revised the manuscript for important intellectual content and gave final approval. Mihaela Marin contributed substantially to the analysis and interpretation of data, drafted the manuscript and gave final approval. Twenty-three sites across Canada (respirologists, internists, and family practitioners) participated in this study. The authors thank the physicians responsible for the clinical care and assessment of the patients. The investigators consisted of: A Kelly and S Lam (Alberta); T Fera, D Hepburn, and P White (British Columbia); P Mehta and K Saunders (Manitoba); R Michael (Nova Scotia); PG Cox, A Dhar, T Fargher, I Ferreira, A Kaplan, WP Killorn, A Lam, R Luton, MR Maleki-Yazdi, M Miller, J Nemni and R Shemilt (Ontario); M Labbe, B Pek, and L Theriault (Quebec). The authors also thank the following individuals at OptumInsight who were involved in the study at various stages: Heather Bennett, Megan Coombes, Jennifer Haig, Shelley Lee, Victoria Porter, Nicki Protopapas and Raina Rogoza. The authors also thank Heide Hass from Novartis, who was involved in the study.

FUNDING: The authors are grateful to Novartis (Canada) Inc for funding this study.

\section{REFERENCES}

1. O'Donnell DE, Hernandez P, Kaplan A, et al. Canadian Thoracic Society recommendations for management of chronic obstructive pulmonary disease: 2008 update highlights for primary care. Can Respir J 2008;15:1A-8A.

2. Global Initiative for Chronic Obstructive Lung Disease. Global strategy for the diagnosis, management, and prevention of chronic obstructive pulmonary disease (updated 2010) <www.goldcopd.org> (Accessed October 20, 2011).

3. Donaldson GC, Seemungal TAR, Bhowmik A,Wedzicha JA. Relationship between exacerbation frequency and lung function decline in chronic obstructive pulmonary disease. Thorax 2002;57:847-52.

4. Seemungal TA, Donaldson GC, Paul EA, Bestall JC, Jeffries DJ, Wedzicha JA. Effect of exacerbation on quality of life in patients with chronic obstructive pulmonary disease. Am J Respir Crit Care Med 1998;157:1418-22.

5. Canadian Institute for Health Information. Health Indicators 2008. Ottawa: Canadian Institute for Health Information, 2008:21.

6. Miravitlles M, Murio C, Guerrero T, Gisbert R; DAFNE Study Group. Pharmacoeconomic evaluation of acute exacerbations of chronic bronchitis and COPD. Chest 2002;121:1449-55. 
7. Soler-Cataluña JJ, Martinez-Garcia MA, Roman Sanchez P, Salcedo E, Navarro M, Ochando R. Severe acute exacerbations and mortality in patients with chronic obstructive pulmonary disease. Thorax 2005;60:925-31.

8. Maleki-Yazdi MR, Lewczuk CK, Haddon JM, Choudry N, Ryan N. Early detection and impaired quality of life in COPD GOLD Stage 0: A pilot study. COPD 2007;4:313-20.

9. Life and Economic Burden of Lung Disease in Ontario: 2011 to 2041, pages 131-2. < www.on.lung.ca/document.doc?id=872> (Accessed October 20, 2011).

10. Gershon AS, Warner L, Cascagnette P, Victor JC, To T. Lifetime risk of developing chronic obstructive pulmonary disease: A longitudinal population study. Lancet 2011;378:991-6.

11. Bolton CE, Ionescu AA, Edwards PH, Faulkner TA, Edwards SM, Shale DJ. Attaining a correct diagnosis of COPD in general practice. Respir Med 2005;99:493-500.

12. Caramori G, Bettoncelli G, Tosatto R, et al. Underuse of spirometry by general practitioners for the diagnosis of COPD in Italy. Monaldi Arch Chest Dis 2005;63:6-12.
13. Walters JA, Hansen E, Mudge P, Johns DP, Walters EH, Wood-Baker R. Barriers to the use of spirometry in general practice. Aust Fam Physician 2005;34:201-3.

14. Jansson SA, Andersson F, Borg S, Ericsson A, Jönsson E, Lundbäck B. Costs of COPD in Sweden according to disease severity. Chest 2002;122:1994-2002.

15. Chapman KR, Bourbeau J, Rance L. The burden of COPD in Canada: Results from the Confronting COPD Survey. Respir Med 2003;97:S23-31.

16. Mittmann N, Kuramoto L, Seung SJ, Haddon JM, Bradley-Kennedy C, Fitzgerald JM. The cost of moderate and severe COPD exacerbations to the Canadian healthcare system. Respir Med 2008;102:413-21.

17. Ontario Case Costing Initiative (OCCI), years 2007/2008. <www.occp.com> (Accessed March 8, 2010).

18. European Community for Coal and Steel. Standardization of lung function tests. Bull Eur Physiopathol Respir 1983;19(Suppl):1-93. 


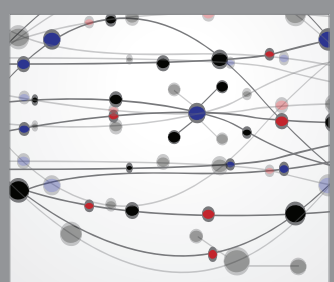

The Scientific World Journal
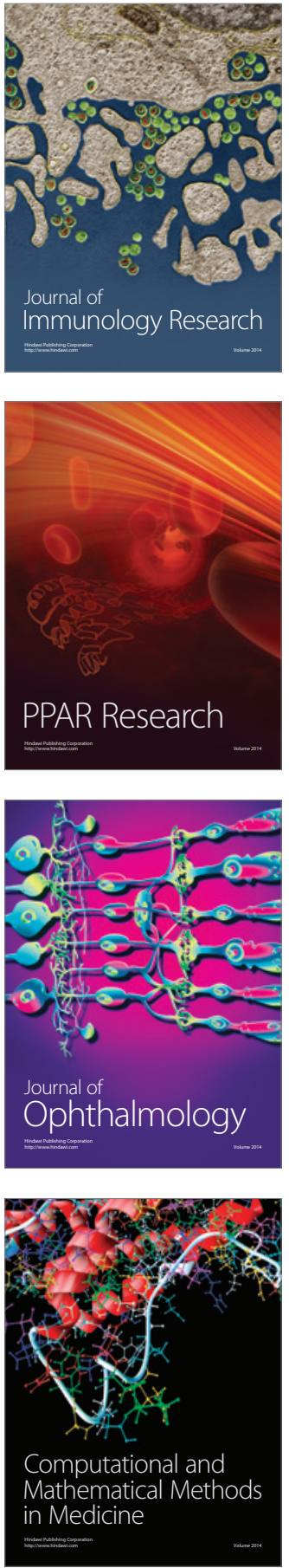

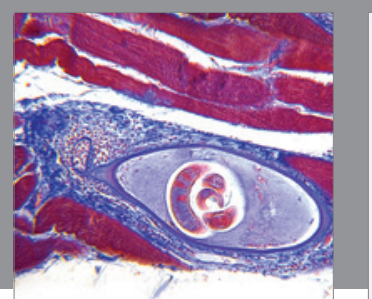

Gastroenterology Research and Practice

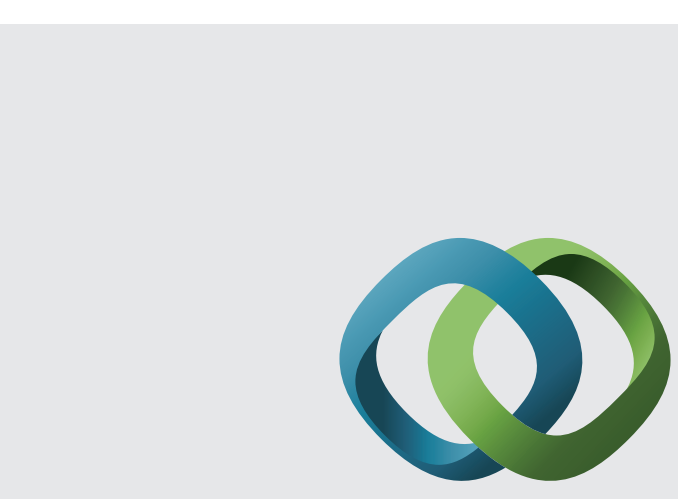

\section{Hindawi}

Submit your manuscripts at

http://www.hindawi.com
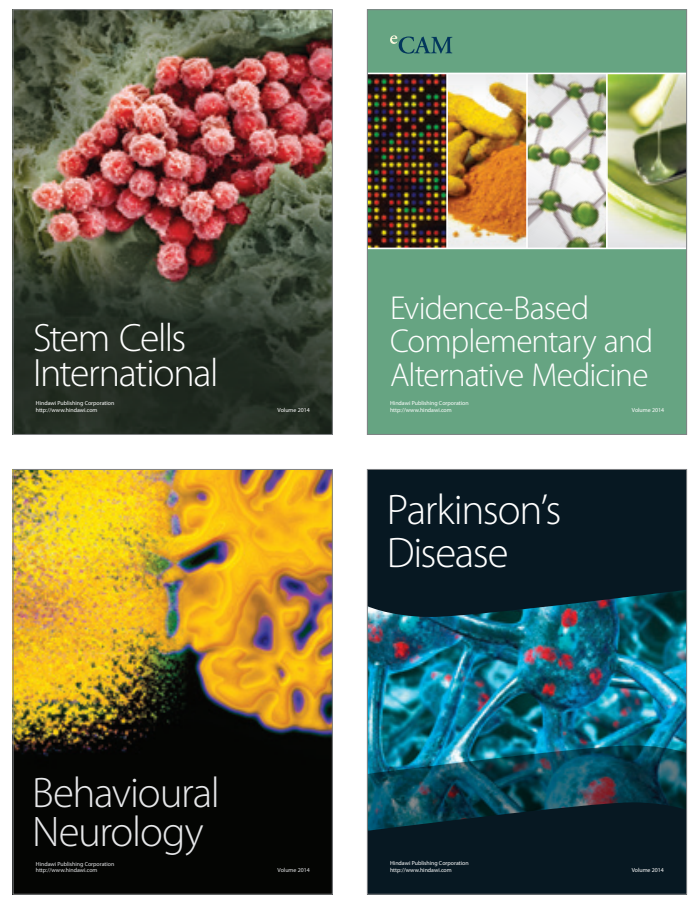
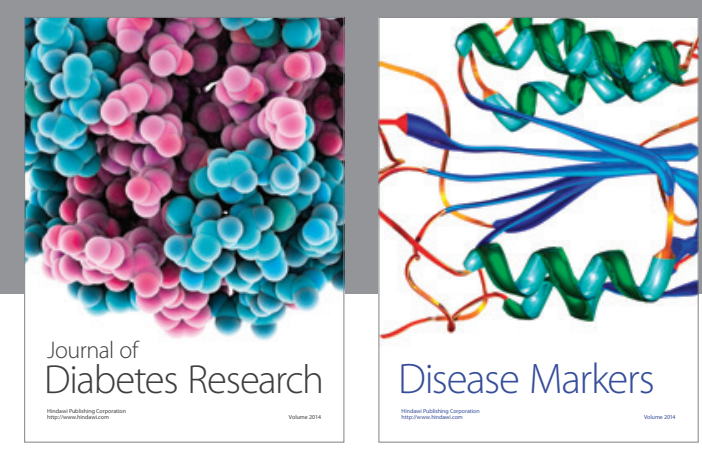

Disease Markers
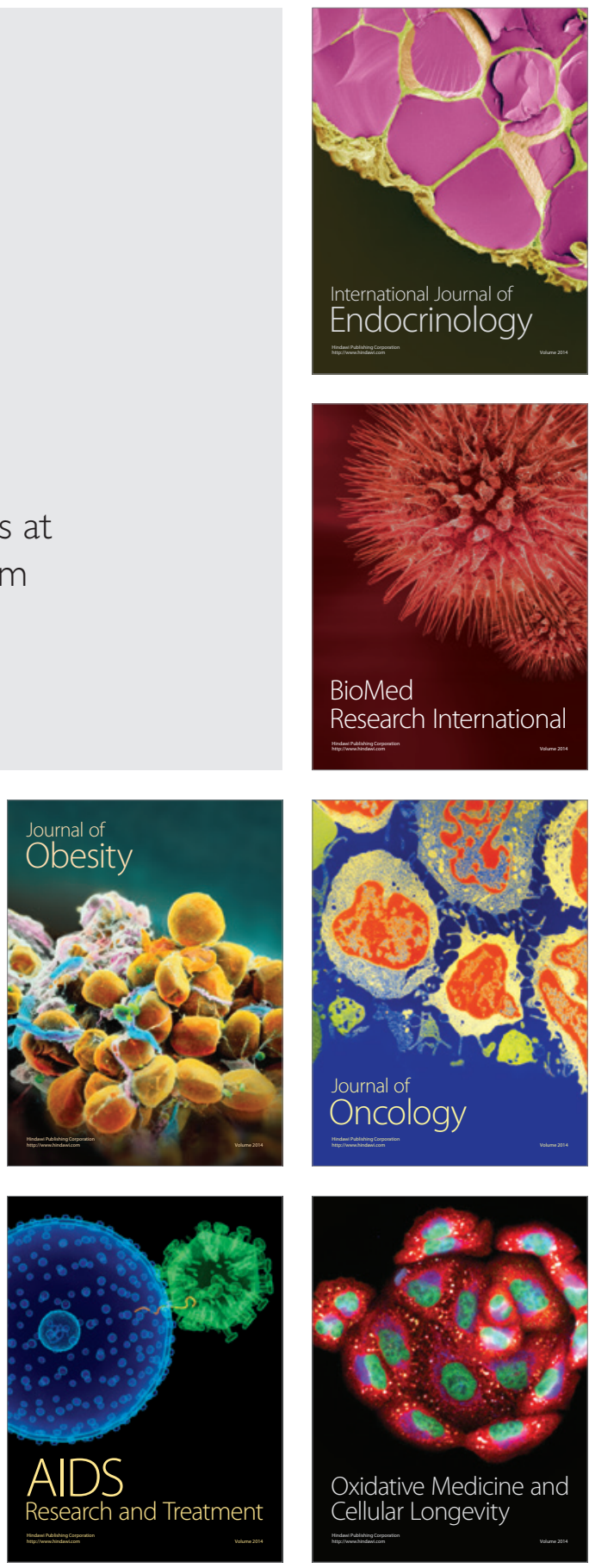